\title{
Serum C-reactive protein measurement in the detection of intercurrent infection in Oriental patients with systemic lupus erythematosus
}

\author{
C R K HIND ${ }^{1}$, S C NG ${ }^{2}$, P H FENG ${ }^{2}$, AND M B PEPYS
}

From the ${ }^{1}$ Medical Research Council Acute Phase Protein Research Group, Immunological Medicine Unit, Department of Medicine, Royal Postgraduate Medical School, London W12 OHS; and the ${ }^{2}$ Department of Medicine IV, Tan Tock Seng Hospital, Singapore 1130

SUMMARY In a prospective study serum C-reactive protein (CRP) concentrations were $\stackrel{N}{\circ}$ measured during 28 febrile episodes in 27 Oriental patients with systemic lupus erythematosus 은 (SLE). Although active SLE was associated with only a modest rise in serum CRP level, intercurrent infection provoked substantially higher levels. Serum CRP thus provides a sensitive objective test for this complication in SLE patients of all ethnic groups.

Intercurrent infection, with fever, is a common complication, in patients with systemic lupus erythematosus, both of the disease itself and of the drugs used in its treatment. In addition fever is a frequent symptom of disease activity in SLE, both at the time of initial diagnosis and during subsequent exacerbations of disease. ${ }^{12}$ The distinction between infection and disease activity as the cause of fever is often difficult but clearly of great importance in the management of the SLE patient.

Unlike most inflammatory and tissue-damaging disorders active SLE in Caucasians is usually associated with only a modest rise in the serum concentration of CRP, the classical acute phase protein, though these patients may show a more pronounced CRP response after infection or trauma. ${ }^{3-6}$ Although there has been some controversy, ${ }^{7}$ we have previously reported that serum CRP measurement provides a quick, objective test for detecting intercurrent infection in patients with SLE. $^{8}$ In a prospective study of 124 Caucasian patients with SLE a serum CRP level greater than $60 \mathrm{mg} / \mathrm{l}$ in a febrile patient strongly suggested the presence of infection, while a CRP level below $30 \mathrm{mg} / 1$ in an ill patient excluded serious, systemic infection. ${ }^{8}$

Accepted for publication 8 November 1984.

Correspondence to Professor M B Pepys, MRC Acute Phase Protein Research Group, Immunological Medicine Unit, Department of Medicine, Royal Postgraduate Medical School, Du Cane Road, London W12 0HS.
The mechanism or mechanisms for the poor CRP response in SLE are not known. One possibility is that the disease process of SLE may not itself

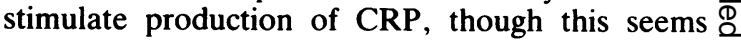
unlikely in view of the extensive inflammation and $\overrightarrow{\vec{A}}$ tissue destruction seen in this disorder. Alternatively SLE patients may be genetically 'low CRP responders', at least to their own disease process. Some support for this hypothesis is found in a mouse model of spontaneous autoimmune disease, the $(\mathrm{NZB} \times \mathrm{NZW}) \mathrm{F}_{1}$ strain, which develops a chronic inflammatory disease resembling human SLE. These mice completely fail to mount any acute phase response during evolution of their pathology but respond normally to other, intercurrent acute phase stimuli. ${ }^{9}$

The possibility that production of human CRP in response to some stimuli may also be under genetic $N_{0}$ control prompted us to study the CRP response in a group of Oriental SLE patients, in order to compare 0 their behaviour with that of their Caucasian counter- $\mathcal{\omega}$ parts. We report here that in a series of 27 Oriental 2 patients there was only a modest CRP response to $\varrho$ active SLE, and that intercurrent infection pro- $\mathbb{D}$ voked the same major CRP response that we have $\stackrel{-}{-}$ previously reported in infected Caucasian patients with SLE.

Patients and methods

Between July 1982 and November 1983 serum CRP 
concentrations were measured by electroimmunoassay during 28 febrile episodes in 27 patients with SLE ( 25 female, 2 male; mean age 25 years, range 11-44). There were 19 Chinese patients, three Malaysian, three Indian, and two Phillipino patients. All had features of SLE which satisfied the American Rheumatism Association (ARA) criteria for the classification of the disease. ${ }^{(1)}$ The disease activity when the blood sample was taken was assessed by criteria similar to those reported previously, ${ }^{8}$ and each patient was assigned to active lupus or infection groups. Infection was diagnosed only on the basis of a positive culture, except where the clinical picture strongly suggested the presence of infection, and where the clinical context was one in which positive cultures are frequently difficult to obtain.

\section{Results}

During the study there were 19 febrile episodes due to active SLE and nine due to infection. The

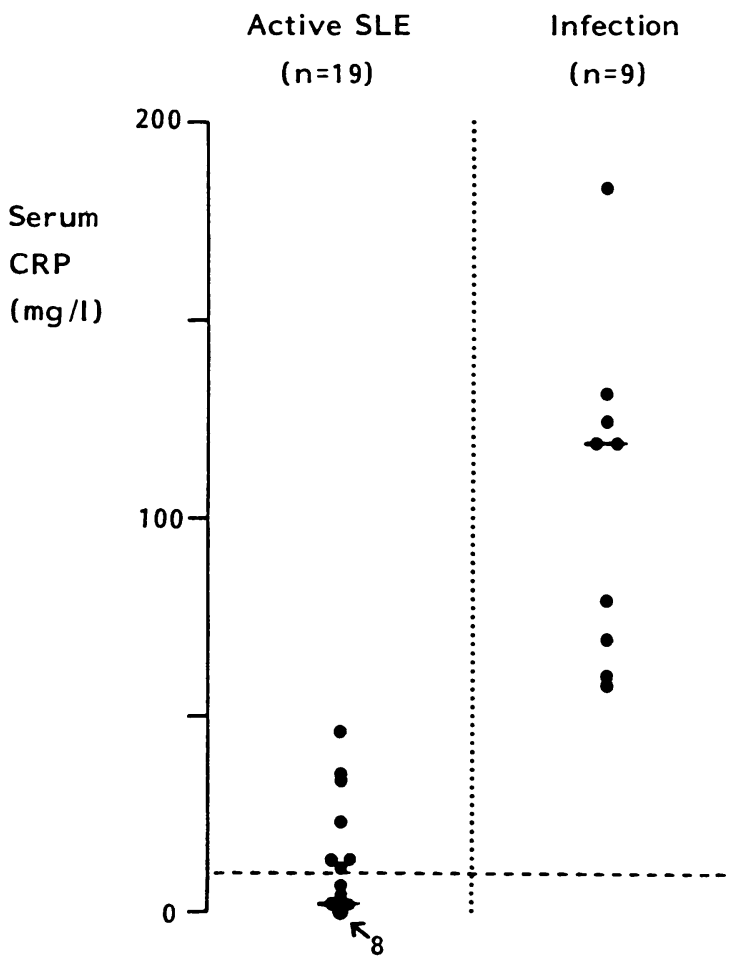

Fig. 1 Serum CRP concentrations in Oriental patients with $S L E$, with febrile episodes due to active lupus alone or due to intercurrent infection. Horizontal bars indicate the medians for each group. $90 \%$ of normal healthy individuals have a serum CRP concentration below $3 \mathrm{mg} / \mathrm{l}$ and $99 \%$ below $10 \mathrm{mg} / \mathrm{l}$ (interrupted lines). individual serum CRP concentrations in each of these two groups are shown in Fig. 1. The difference was clearly apparent (Wilcoxon rank sum test, $\mathrm{p}<0 \cdot 01$ ), with no overlap between the serum CRP concentrations. The results in Oriental SLE patients were very similar to those found in Caucasians. Active SLE was associated with only a modest rise in serum CRP level, the highest level seen being 46 $\mathrm{mg} / \mathrm{l}$, and in some cases there was no increase at all. In contrast intercurrent infection provoked substantially higher levels of serum CRP and thus provided a sensitive objective test for this potentially serious complication in all ethnic groups.

\section{Discussion}

The present observations support the view that the failure of individuals with SLE to mount a major acute phase response to their own disease, while retaining their capacity to respond to extrinsic stimuli, is an integral part of the condition. It remains to be determined whether this "low responder' status is genetically determined and therefore potentially primary or of other pathogentic significance.

This work was supported by a MRC Programme Grant to Professor M B Pepys. Dr C R K Hind is the recipient of a MRC Training Rescarch Fellowship.

\section{References}

1 Rothficld N. Clinical features of systemic lupus crythematosus. In: Kelley W N. Harris E D. Ruddy S. Sledge C B, eds. Textbook of rheumatology. Philadelphia: Saunders, 1981: $1106-32$.

2 Stahl N I, Klippel J H. Decker J. Fever in systemic lupus crythematosus. Ain J Med 1979: 67: 935-40.

3 Honig S. Gorevic P. Weissmann G. C-reactive protein in systemic lupus crythematosus. Arthritis Rheum 1977; 20: $1065-70$.

4 Becker G J. Waldburger M. Hughes G R V. Pepys M B. Value of serum $C$-reactive protein measurement in the investigation of fever in systemic lupus erythematosus. Ann Rheum Dis 1980; 39: $50-2$.

5 Bravo M G. Alarcon-Scgovia D. C-reactive protein in the differential diagnosis between infection and disease reactivation in SLE. J Rheumatol 1981; 8: 291-4.

6 Perreira da Silva J A. Elkon K. Hughes G R V, Dyck R F, Pepys M B. CRP levels in systemic lupus erythematosus - a classification critcrion? Arthritis Rheum 1980: 23: 770-1.

7 Zein N. Ganuza C. Kushner 1. Significance of serum Creactive protcin elevation in paticnts with systemic lupus crythematosus. Arthritis Rheum 1979: 22: 7-12.

8 Pepys M B, Lanham J G. De Bcer F C. C-reactive protein in SLE. Clin Rheum Dis 1982: 8: 91-103.

9 Rordorf C. Schncbli H P. Baltz M L. Tennent G A. Pepys M B. The acute phase response in $(\mathrm{NZB} \times \mathrm{NZW}) \mathrm{F}_{1}$ and $\mathrm{MRL} / \mathrm{I}$ mice. J Exp Med 1982: 156: 1268-73.

10 Cohen A S. Reynolds W E. Franklin E C. et al. Preliminary criteria for the classification of systemic lupus erythematosus. Bull Rheum Dis 1971: 21: 643-8. 